\title{
FOOD SAFETY MANAGEMENT LEADERSHIP STYLE: TRANSFORMATIONAL OR TRANSACTIONAL?
}

\author{
Agus Purwanto $^{1 *}$, Leo Hutagalung ${ }^{2}$, Evy Yanthy $^{3}$ \\ ${ }^{1,2,3}$ Post graduate Programme \\ University of Pelita Harapan, Banten, Indonesia \\ *Corresponding Author: agozpor@gmail.com
}

\begin{abstract}
The purpose of this study was to analyze the effect of transformational and transactional leadership style on the performance of the latest version of the FSSC 22000 (Food Safety System Certification) food safety management system, version 5 of 2019 in the food industry in Tangerang. The object of the research were employees in several food industries that worked in the Tangerang City area who had implemented FSSC 22000 version 5 2019; as many as 120 people, and data collection method was done by giving out electronic questionnaire to several employees randomly. The analysis tool in this study used SEM (Structural Equation Model) LISREL program version 8.70. The results showed that the transformational leadership style positively and significantly affected the performance of the FSSC 22000 implementation and the transactional leadership style also contributed positive effect on the performance of the FSSC 22000 food safety management system and it can be concluded that leadership was important for the implementation of the FSSC 22000 Food Safety Management System.
\end{abstract}

Keywords: Transfromational Leadership; Transactional; FSSC 22000

Received November ${ }^{25 \text { th }} 2019 \quad$ Revision January ${ }^{10 \text { th }} 2020 \quad$ Accepted for Publication January ${ }^{19 \text { th }} 2020$

\section{INTRODUCTION}

In May 2019, FSSC 22000 new edition, version 5 was published and is applied for food manufacturing activities, food packaging manufacturing, animal feed production, agriculture as well as new food transportation and storage, catering and retail and wholesale and with changes in ISO 9001: 2015 and ISO 14001: 2015, the new version of FSSC 22000 is also a risk-based standard (ISO.org, 2019). In the industry 4.0 era, the level of industrial competition is increasingly fierce, especially the food and beverage industry and in order to maintain the viability of the company, it requires a high performance of the overall human resources. The application of the FSSC 22000 food security management system in the food industry ensures that the products produced are safe and will increase the competitiveness of companies in the global market (Segovia et al, 2014). Some foodproducing companies that apply FSSC 22000 with foreign market share apply FSSC 22000 to increase efficiency, productivity and product quality and many food companies are unaware of the potential benefits of its application and feel the high costs associated with implementation (Maria et al, 2014). The main barriers to the implementation of the FSSC 22000 food safety management system in general are a lack of financial resources, inadequate size of the organization, infrastructure and facilities, and a lack of top management commitment, the main motivation for FSSC 22000 implementation is to 
improve product quality and safety and improve employee skills, improve image company, increasing product sales, increasing market share, and access to new markets (ISO.org, 2018). In clause 5, in the FSSC 22000: 2019 standard, it requires the importance of leadership and commitment from top management so that its implementation can run well, top management must demonstrate leadership and commitment, establish, implement, and maintain food safety policies (Dwiantoro et al, 2014).

Several previous studies with the topic of the effect of leadership style on performance such as (Dwiantoro et al, 2014) has examined that transformational leadership style has a significant positive effect on performance, transactional leadership style has a significant negative effect on performance. Rahim et al. (2018) examined that transformational leadership affects employee performance and transactional leadership does not affect employee performance. Isnawati et al. (2016) conducted a study and concluded that the transformational leadership style affects performance. Transactional leadership style has no effect on performance. Aqmarina et al (2018) conducted a study and concluded that transformational leadership has a negative and insignificant effect on employee performance while transactional leadership has insignificant effect on employee performance.

Wahyuniardi et al. (2014) conducted a study and concluded that transformational leadership has a significant effect on job satisfaction, transformational leadership does not significantly influence employee performance, organizational culture does not significantly affect employee performance and job satisfaction does not significantly affect performance employees. To improve employee performance, it can be done by increasing job satisfaction. If job satisfaction increases, employee performance will increase as well. Birasnav et al. (2015) has also conducted research on leadership and the results of his research show that transformational leadership style and transactional leadership style have a strong and positive effect on organizational performance after controlling the effects of transactional leadership. Research conducted by Tsai et al (2015) and Klüche et al. (2019) concluded that food safety provides benefits to companies.

This research is in an industrial company engaged in bottled beverages located in Tangerang and has implemented a FSSC 22000: 2018 food safety management system for 1 year as a company commitment to maintain the quality of its products. Currently,there are someissues that the FSSC 22000: 2019 implementation has not been optimally seen from every implementation of internal audit, there are still many findings regarding the implementation itself. In 2018, there were 6 major findings and 21 minor findings while in 2019, there were 3 major findings and 34 minor findings. With the presence of these findings, itindicate that the application of the FSSC 22000: 2019 quality management system has not proceeded well. According to the statements of several employees, one of the causes of the non-optimal application of FSSC 22000: 2019 is because the involvement of top and middle leaders is not optimal. Therefore, in this study, the researcher wanted to 
know the effect of transformational and transactional leadership style on the performance of the implementation of FSSC 22000: 2019.

Several previous studies have discussed the effect of leadership on performance in general and this research will discuss more specifically on the performance of the implementation of food safety management systems FSSC 22000: 2019. The purpose of this study was to analyze the effect of transformational and transactional leadership style on the performance of the implementation of security management systems FSSC 22000: 2019.

\section{RESEARCH METHODS}

\section{Research and Hypothesis Framework}

Based on the results of previous studies, the research concept framework is obtained as follows:

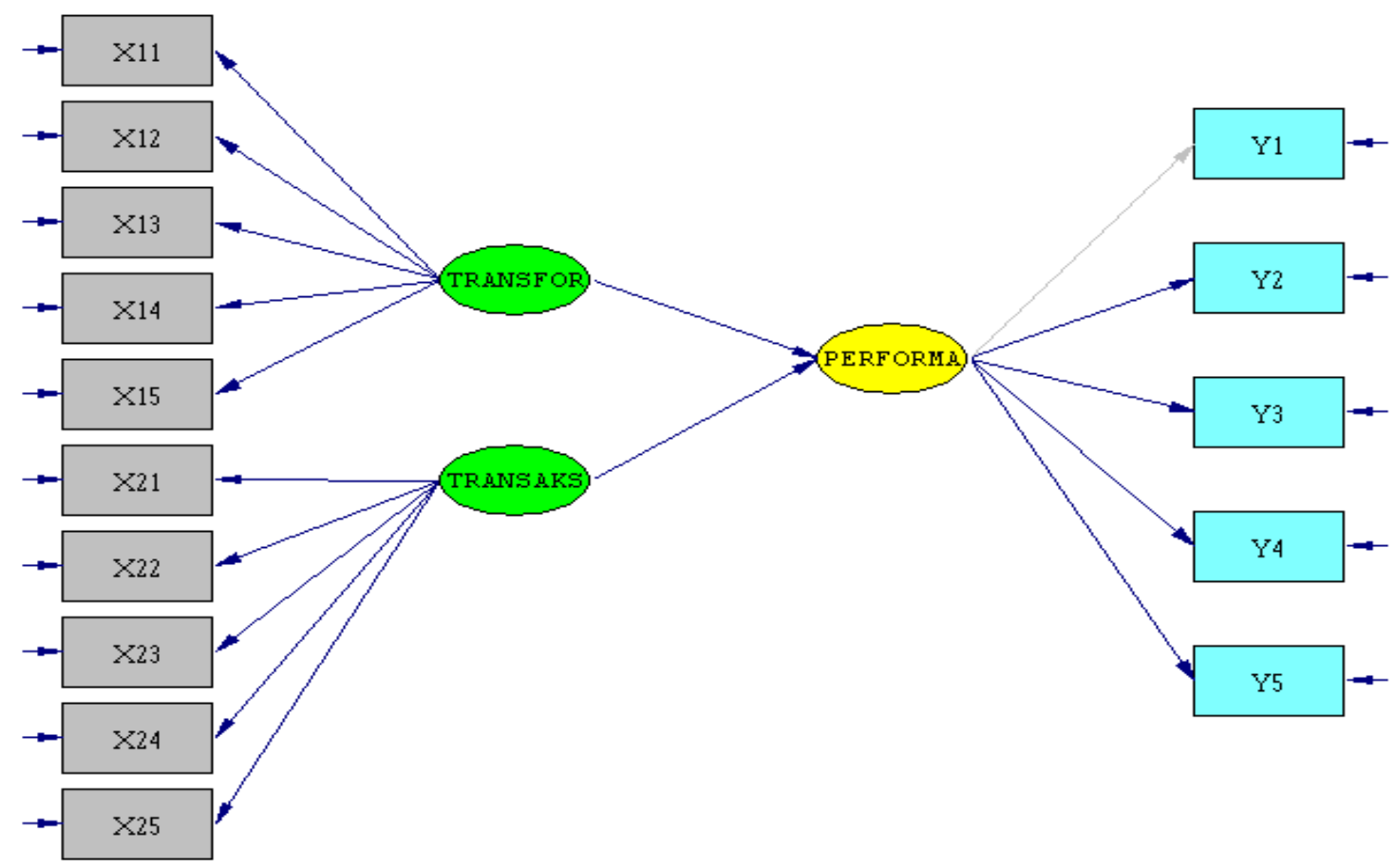

Figure 1.Research Concept Framework

Based on the concept above, the following hypothesis is obtained:

1) It is expected that there is a significant effect of transformational type leadership style (X1) on the performance of the application of food safety management systems ISO 2200: $2018(\mathrm{Y})$.

2) It is expected that there is a significant effect of the transactional type (X2) leadership style on the performance of implementing a food safety management system ISO 2200: $2018(\mathrm{Y})$.

For hypothesis 1 , the independent variable is the transformational leadership style $\left(\mathrm{X}_{1}\right)$ while the dependent variable is the performance of implementing the FSSC 22000: 
2019 (Y) food safety management system. For hypothesis 2, the independent variable is the transactional leadership style $\left(\mathrm{X}_{2}\right)$ while the dependent variable is the performance of the implementation of FSSC 22000: 2019 (Y) food safety management system.

\section{Data Collection Technique}

Data needed in this study is primary data from respondents. The primary data collection method used an electronic questionnaire with a Likert scale. The answer to each statement made five alternative answers and the assessment for each answer was given a scale as follows; Never (TP) score: 1, b). Almost Never (HTP) score 2, c). Sometimes (KK) score 3, d).Often (SR) score 4 and e).Always (SL) score 5.

Indicators on the transformational leadership variable $\left(\mathrm{X}_{1}\right)$ are Charisma, Inspirational, Intellectual stimulation, and Individual consideration factors with 5 statement items. While indicators on the transactional leadership style variable includescontingent reward, by-exception management: (active and passive) and Laissezfaire. Indicators for employee performance variables include factors such as employee work quantity, work quality, efficiency, employee effort, professional standards, accuracy and creativity with 5 statement items. The population in this study were 88 employees of PLC of food industry and all of the population made respondents called the census method.

Table 1

Profile of respondents according to education level

\begin{tabular}{|c|c|c|}
\hline No & Education & Total \\
\hline 1 & SMK & 48 \\
\hline 2 & D3 & 32 \\
\hline 3 & $\mathrm{~S} 1$ & 28 \\
\hline 4 & $\mathrm{~S} 2$ & 12 \\
\hline \multicolumn{2}{|c|}{ Total } & 120 \\
\hline
\end{tabular}

Source: Processed Internal Data

Table 2

Profile of respondents according to working period

\begin{tabular}{|c|c|c|}
\hline No & Working Period (Year) & Total \\
\hline 1 & $0-5$ & 39 \\
\hline 2 & $6-10$ & 41 \\
\hline 3 & $11-15$ & 26 \\
\hline 4 & $16-20$ & 14 \\
\hline \multicolumn{2}{|r|}{ Total } & 120 \\
\hline
\end{tabular}

Source: Processed Internal Data

Table 3

Profile of respondents by department 


\begin{tabular}{|c|c|c|}
\hline No & Department & Total \\
\hline 1 & Production & 42 \\
\hline 2 & Warehouse & 30 \\
\hline 3 & Quality Control & 27 \\
\hline 4 & Office & 21 \\
\hline \multicolumn{2}{|c|}{ Total } & 120 \\
\hline
\end{tabular}

Source: Processed Internal Data

Based on the respondent profile data above, it has been shown that the respondent's distribution is evenly distributed from the level of working period, education and department where they carry out work activities.

\section{Data Analysis Technique}

Analysis of the data in this study usedStructural Equation Modeling (SEM) with Linear Structural Model (LISREL) software tools. With the Lisrel software, you can test the relationship between latent variables and their indicators. The value of construct validity and reliability of each indicator in this study could be done by using Confirmatory Factor Analysis (CFA). Testing the validity and reliability was done by using confirmatory factor analysis in order to obtain valid and reliable data. Second order confirmatory factor analysis (2nd Order CFA) is a measurement model that consists of two levels.First, the analysis was carried out from the latent construct aspect to each of its indicators. Then, the analysis will be carried out from the latent construct to the construct of its aspects. Not only could CFA be tested for construct validity, it can also do construct reliability testing. The construct is said to have good reliability is if the value of Construct Reliability $(\mathrm{CR}) \geq$ 0.70 and the extracted variance value $\geq 0.50$ measure of reliability construct can be concluded well if the value is more than 0.40 .

\section{RESULTS AND DISCUSSION}

Williams, et al. (2012) conducted a study using the LISREL 8.71 Software and the initial stage of analysis was that we create a research model or what is commonly referred to as a path diagram, then connect the variables. Then, the data obtained from the results of the questionnaire collection is being input into a LISREL or excel or SPSS file, then saved in the format .psf or .csv or .txt or .dat. after the data is converted to .psf format then the data is processed using LISREL 8.71. The method for data analysis can be done by using Structural Equation Model (SEM), namely Linear Structural Model (LISREL) software version 8.71 from Joreskog and Sorbom (2008) through the $2^{\text {nd }}$ Order CFA with criteria for loading factor values $(>0.5)$ and for $t$ count values $(>1.96)$ the results are shown in the following image: 


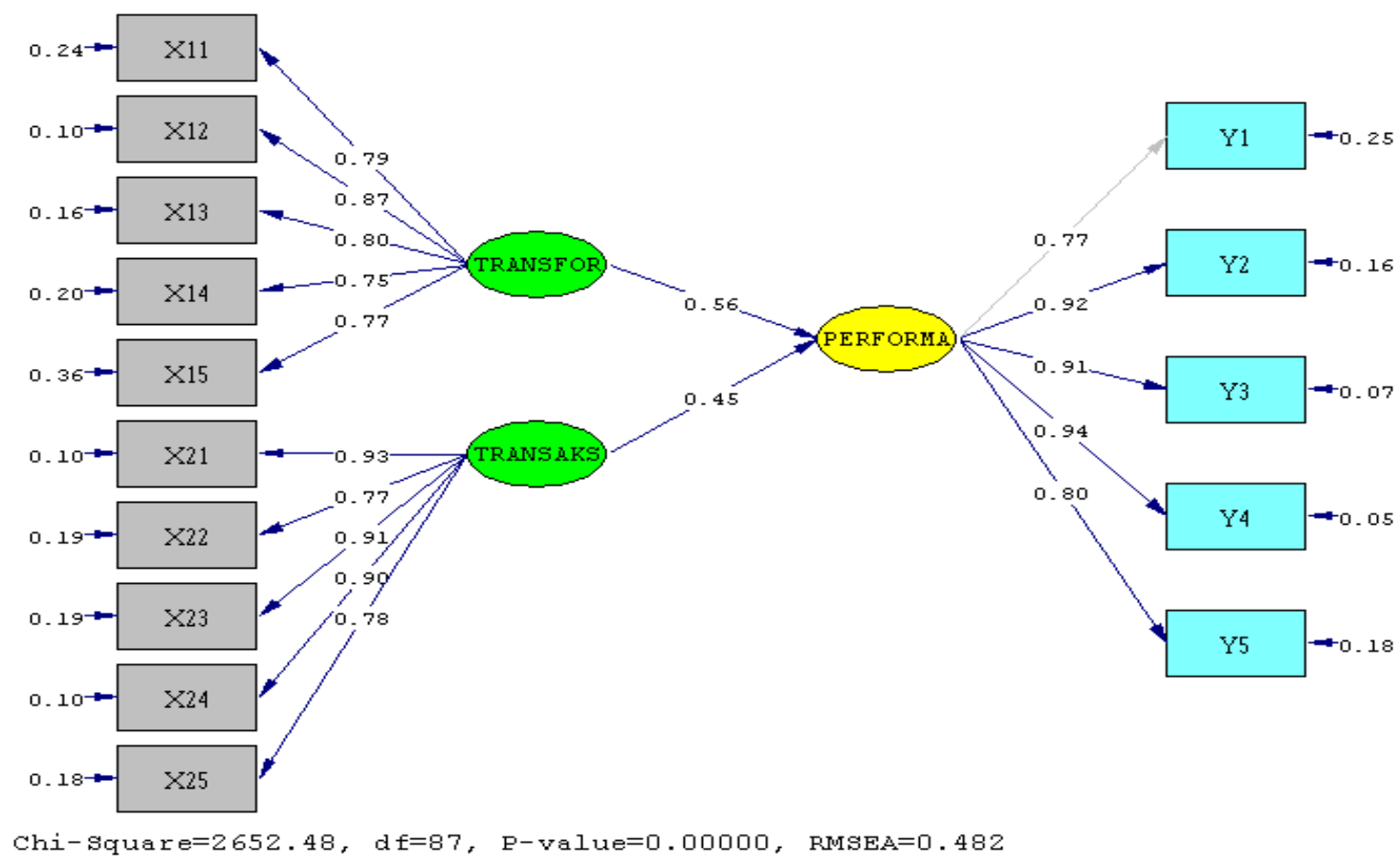

Figure 2.The value of loading factor order CFA

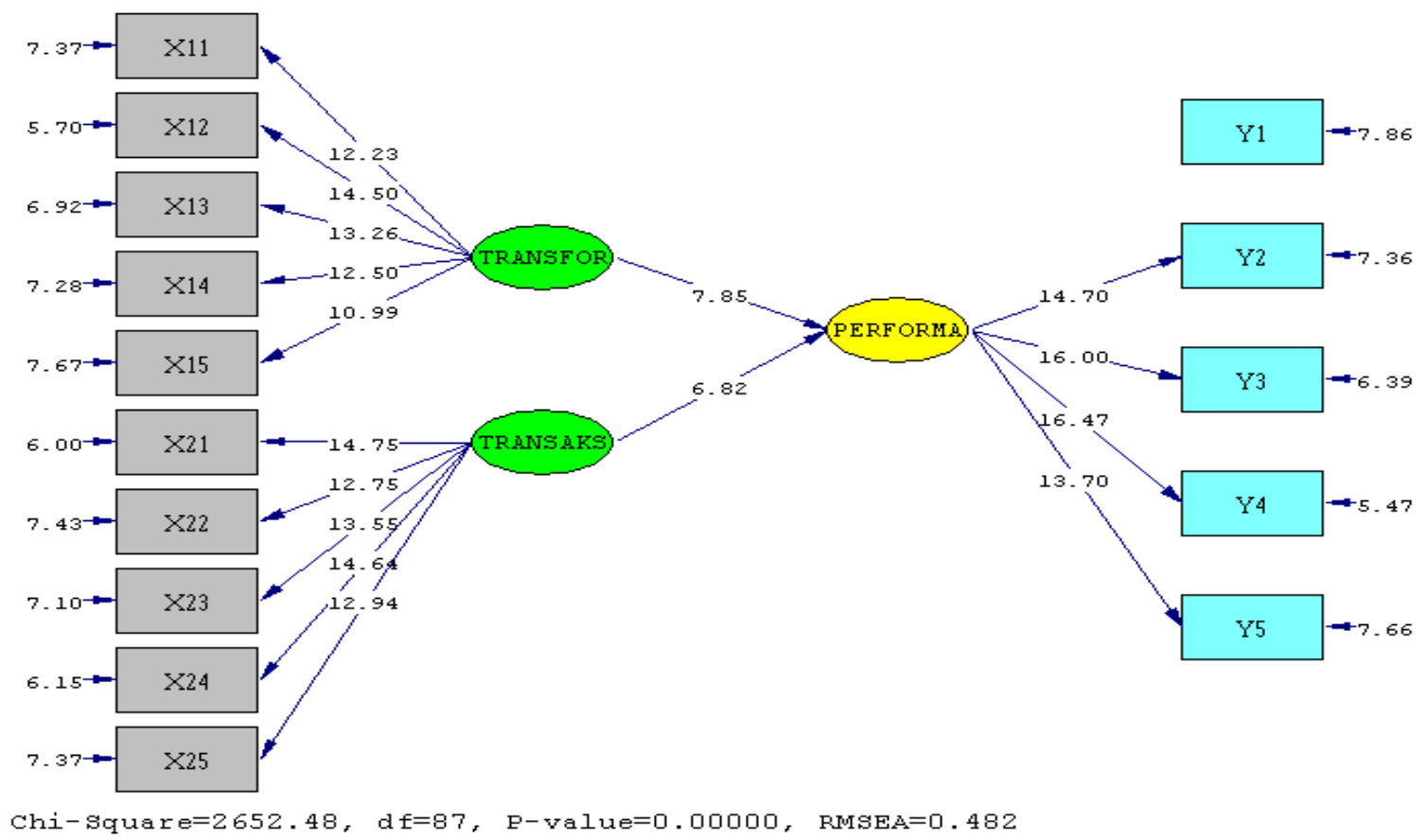

Figure 3.The Value of $t$ order CFA

Based on Figure 1 and Figure 2, it can be seen that there is no negative error variance value, because there is no error variance value that is negative. If there is an error variance that is negative, then the observed variables in the equation will be removed from the model. The initial step of the analysis is carried out from the latent construct of the aspects to the indicators. Based on the result of the analysis of the data above, it shows that the value of the loading factors are all above $0.5(>0.5)$ and all the calculated t values that are needed to test the significance of the factor loading values are higher than $1.96(>1.96)$. 
This is to say that all items are valid and significant. The summary of the analysis results above can be seen in the following table:

Table 4

The Analysis of 2nd Order CFA Construct Validity (Aspect-Indicator)

\begin{tabular}{ccccc}
\hline Variable & Item & Loading factor & T-Value & Information \\
\hline & X11 & 0.79 & 12.23 & Sig \\
Transformational leadership & X12 & 0.87 & 14.50 & Sig \\
(X1) & X13 & 0.80 & 13.26 & Sig \\
& X14 & 0.75 & 12.50 & Sig \\
& X15 & 0.77 & 10.99 & Sig \\
& X21 & 0.93 & 14.75 & Sig \\
Transactional leadership & X22 & 0.77 & 12.75 & Sig \\
(X2) & X23 & 0.91 & 13.55 & Sig \\
& X24 & 0.90 & 14.64 & Sig \\
& X25 & 0.78 & 12.94 & Sig \\
FSSC 22000 Performance & Y1 & 0.77 & & \\
Y2 & Y3 & 0.92 & 14.70 & Sig \\
& Y4 & 0.91 & 16.10 & Sig \\
& Y5 & 0.90 & 16.47 & Sig \\
& & & 13.70 & Sig \\
\hline
\end{tabular}

Source: Processed Internal Data

The second level of analysis follows from the latent construct to its aspect construct. Based on the test results above, it is found that the value of the whole loading factor is obtained above $0.5(>0.5)$ and all t-values which are required to test the significance level of the factor loading value are higher than 1.96 (> 1.96). The summary of the analysis results above can be seen in table 5 .

\section{Table 5}

The Analysis of 2nd Order CFA Construct Validity (Latent-Aspect)

\begin{tabular}{ccccc}
\hline Variable & Item & Loading factor & T-Value & Information \\
\hline $\begin{array}{c}\text { Transformational } \\
\text { leadership }\end{array}$ & $\mathrm{X} 1$ & 0.56 & 7.85 & $\mathrm{Sig}$ \\
\hline
\end{tabular}

Source: Processed Internal Data

These results can be concluded that both aspects which consist of transformational leadership style and transactional leadership style are valid and significant. The results of the validity are also strengthened with the value of Chi Square (r) which produces a value of 2652.48. Based on the formula of the calculation of the reliability construct, it obtained CR result of 0.84 and VE of 0.73 which can conclude that the variables have good reliability. Hair (2010) states that the construct value has good reliability when the Construct Reliability (CR) value $\geq 0.07$ and the extracted variance value (VE) $\geq 0.40$. 
Table 6

The Result ofCFA Construct Reliability OCB 2nd Order Analysis

\begin{tabular}{cccccc}
\hline Variable & Item & LoadingFactor & Error & CR & VE \\
\hline & X11 & 0.79 & 0.24 & & \\
Transformational & X12 & 0.87 & 0.10 & & \\
leadership (X1) & X13 & 0.80 & 0.16 & & \\
& X14 & 0.75 & 0.20 & & \\
& X15 & 0.77 & 0.36 & & \\
& X21 & 0.93 & 0.10 & & \\
Transactional & X22 & 0.77 & 0.19 & & \\
leadership (X2) & X23 & 0.91 & 0.10 & 0.84 & 0.73 \\
& X24 & 0.90 & 0.18 & & \\
& X25 & 0.78 & 0.25 & & \\
& Y1 & 0.77 & 0.16 & & \\
Performance (Y) & Y2 & 0.92 & 0.07 & & \\
& Y3 & 0.91 & 0.05 & & \\
& Y4 & 0.90 & 0.10 & & \\
\hline
\end{tabular}

Source: Processed Internal Data

Thus, based on the results of the analysis of the calculation of reliability above, it can be concluded that the reliability of the measurement model is good. Testing measurement model, it has been proven that the research meets the requirements of all stages of testing.

\section{Analysis ofGoodness of Fit (GOF)}

Test suitability of the model as a whole or as a whole model fit related to the analysis of the GOF statistical values generated by the Lisrel program and the GOF statistics results are shown in Figure 2. For the suitability of the model (model fit) is good enough and for the criteria of the model fit can be seenin the following table.

Table 7

\section{Model FitCriteria}

\begin{tabular}{lccc}
\hline \multicolumn{1}{c}{ Fit Index } & Value & Value Standard & Information \\
\hline $\begin{array}{l}\text { Chi-Square } \\
\text { Root Mean Square Error of }\end{array}$ & 2652.48 & $>0.5$ & Good \\
Approximation (RMSEA) & & & \\
Normed Fit Index (NFI) & 0.11 & $<0.08$ & Poor \\
Non-Normed Fit Index (NNFI) & 0.97 & $>0.90$ & Good \\
Comparative Fit Index (CFI) & 0.98 & $>0.90$ & Good \\
Incremental Fit Index (IFI) & 0.98 & $>0.90$ & Good \\
Relative Fit Index (RFI) & 0.93 & $>0.90$ & Good \\
\hline Source: Processed Internal Data & 0.97 & $>0.90$ & Good \\
\hline
\end{tabular}

Source: Processed Internal Data 
Based on the result above, it can be seen that 6 out of 9 index fit states that the model is fit. These results indicate that the variables are valid and reliable so that it can be concluded that the overall fit of the model is still good.

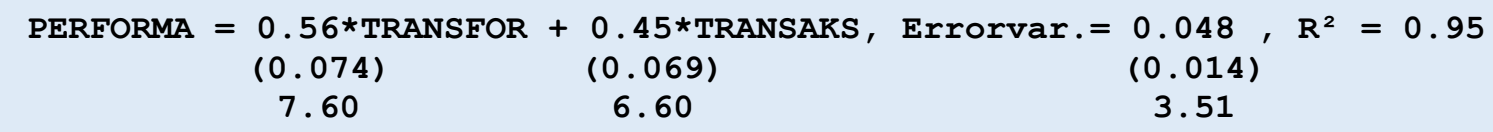

Figure 4. Structural Equations

Based on the results of the above analysis it can be seen that transformational leadership style has a positive and significant effect on the performance of the food safety management system with a statistical $t$ value of 7.85> 1.96 with its unstandardized coefficient of 0.56. Transactional leadership style also positively and significantly influences the performance food safety management system with a statistical t value obtained at 6.60> 1.96 with an unstandardized coefficient of 0.45 . The goodness of fit model that is produced is quite good with a chi square value of 2652 . The other goodness of fit criteria also meet the required conditions. Lisrel software has been widely used to process and analyze data in several studies including Cavusoglu et al (2012) and OleBoe et al. (2010).

\section{The Effect of Transformational Leadership style on FSSC 22000 Performance}

Based on the analysis, it was concluded that the transformational leadership style had a positive and significant effect on the performance of the food safety management system implementation with a statistical value of $t$ of $7.60>1.96$ with a unstandardized standard coefficient of $0.56(56 \%)$. Several previous studies related to the effect of leadership style on performance,for example, Dwiantoro et al (2017) examined that transformational leadership style has a significant positive effect on performance, transactional leadership style has a significant negative effect on performance. Iswatiningsih et al. (2018) examined that there was no significant effect between transformational leadership on employee performance, there was a significant effect between transactional leadership on employee performance.

\section{The Effect of Transactional Leadership style on FSSC 22000 Performance}

Transactional leadership style also has a positive and significant effect on the performance of the food safety management system implementation with a statistical $t$ value 6.60> 1.96 with a unstandardized coefficient of $0.45(45 \%)$. The result of research from Rahim et al (2018) concluded that transformational leadership affects employee performance and transactional leadership does not affect employee performance. Hidayati et al (2014) examined that transformational leadership affects employee performance while transactional leadership has no effect on employee performance. Rosnani et al (2012) transactional leadership does not have a significant positive effect on performance. 
Transformational leadership has a significant positive effect on job satisfaction. Eng Sun et al. (2018) conclude that transformational leadership styles affect performance. Transactional leadership style has no effect on performance. Hamidah et al (2016) transformational leadership has a negative and insignificant effect on employee performance and transactional leadership has insignificant effect on employee performance.

FSSC 22000 (Y) Performance Regression, Transfromational and Transactional Leadership $\mathrm{Y}=\mathbf{0 . 5 6} \times$ Transformational $+\mathbf{0 . 4 5} \times$ Transactional + Error and $\mathrm{R2}=0.95(95 \%)$

Masa'deh (2016) found that transactional and transformational leadership styles have a positive and significant impact on job performance and transactional leadership influences knowledge sharing, transformational leadership does not affect knowledge sharing.Crawford et al. (2005) said transformational leadership predicts knowledge management behavior significantly for 19.5 percent of the variance. The organizational position is a significant prediction of knowledge management with transformational leadership for 21.1 percent of the knowledge management variants. Rao et al (2005) suggested that transformational leadership has a significant positive impact on team performance and transactional leadership has a significant negative effect on team performance. Erkutlu et al (2008), There is a significant relationship between leadership behavior and leadership and organizational effectiveness. Transformational leadership behavior stimulates organizational commitment and job satisfaction in the hospitality industry. $\mathrm{Hu}$ et al. (2010) found a positive and significant relationship between transformational leadership managers and job satisfaction. Taylor et al (2014) visionary leadership has a significant and positive correlation with perceived organizational effectiveness and a significant correlation between high leadership behavior and perceived organizational effectiveness.

\section{CONCLUSIONS}

Based on the research that has been done, it can be concluded that the transformational leadership style variable $\left(\mathrm{X}_{1}\right)$ has a positive and significant effect on the business performance of the beverage industry ( $\mathrm{Y}$ ) and the transactional leadership style variable $\left(\mathrm{X}_{2}\right)$ also has a positive and significant influence on the FSSC 22000 (Y) performance variable. For beverage industry management, it is better to use transformational and transactional leadership styles because both of them have a positive effect on the performance of the food safety management system. food safety management but more effective leadership is a combination or combination of both leadership styles.

For this reason, company leaders must pay attention to the leadership style that will be used for subordinates because leadership style is the most influential factor in improving the performance of the food safety management system. For further researchthat 
will examine the influence of leadership style on the performance of the food security management system can add several other variables that are thought to affect the performance of the food safety management system, for example as motivation, ability or competence of individuals and work culture.

This study has several limitations, the sample does not represent the target population, the number of samples used is not much because of the limited time and cost, the object of this study is only in beverage industry companies even though there are other companies have implemented the FSSC 22000 Food Management System. It was limited to the beverage industry in Tangerang and the results of the questionnaire might not be the same when applied to other industries and other places.

\section{REFERENCES}

Acharry, P. Boonrawd. C.Chianchana, "Evaluation Research of Integrated Productivity and Eco-friendly Development Project for Enterprise in Electrical and Electronics Industry", Procedia - Social and Behavioral Sciences, 2014;116: 2970-2975, https://doi.org/10.1016/j.sbspro.2014.01.690

Asbari, M., Santoso, P., \&Purwanto, A. (2019). Influence of Leadership, Motivation, Competence, Commitment and Culture on ISO 9001:2015 Performance in Packaging Industry, Scholars Journal of Economics, Business and Management, 6(12): 577-582. DOI: http://doi.org/10.36347/sjebm.2019.v06i12.005

Asbari, $\quad$ M., Santoso, $\quad$ P., $\quad$ \&Purwanto, A. (2019).PengaruhKepemimpinandanBudayaOrganisasiTerhadapPerilakuKerjaInovat ifPadaIndustri 4.0. JIM UPB (JurnalIlmiahManajemenUniversitasPuteraBatam), 8(1), 7-15. doi: https://doi.org/10.33884/jimupb.v8i1.1562

Asbari, $\quad$ M., Santoso, $\quad$ P., \&Purwanto, A. (2019).PengaruhIklimOrganisasidanKepemimpinanTransformasionalTerhadapProd uktivitasKerjaInovatifPadaIndustriManufaktur di PatiJawa Tengah.JurnalProduktivitas UniversitasMuhammadiyah Pontianak, 7(1 2020), 6269. doi: DOI : 10.29406/jpr.v7i1.1797

Bouzembrak, M. Klüche,, "Internet of Things in food safety: Literature review and a bibliometric analysis", Trends in Food Science \& Technology: 2019;94: 54-64, https://doi.org/10.1016/j.tifs.2019.11.002

C. E.María,L.S. Vijande,"Reasons and constraints to implementing an FSSC 22000 food safety management system: Evidence from Spain”. Food Control Journal, 2014;40: 50-57, https://doi.org/10.1016/j.foodcont.2013.11.032

E.S.Ong, H. Ariwibowo, Isnawati, "PengaruhKepemimpinanTransformasional, KepemimpinanTransaksional Dan Kebijakan Perusahaan TentangUpahPekerjaTerhadapProduktivitasKerja (StudiPada PT "X" Di Surabaya)".JurnalJeksekutif, $\quad$ 2018;5: 334-335, https://jurnal.ibmt.ac.id/index.php/jeksekutif/article/view/200/168

E. Shih, T.W. Ming, C. Tsai, "Effects of the perception of traceable fresh food safety and nutrition on perceived health benefits, affective commitment, and repurchase 
intention”, Food Quality and Preference,2019;19: https://doi.org/10.1016/j.foodqual.2019.103723

I. F.Segovia,B. Peidro, A.Fuentes, "Implementation of a foodsafety management system according to FSSC 22000 in the food supplement industry: A case study", Food Control Journal,2014; 43: 28-34, https://doi.org/10.1016/j.foodcont.2014.02.042

International Standard Organization, FSSC 22000:2018 Food safety management systems - Requirements for any organization in the food chain.ISO.org, 2018; 2: https://www.iso.org/standard/65464.html

L. Macheka, F. A. Manditsera, R.T. Ngadze, J.Mubaiwa, L. K. Nyanga, "Barriers, benefits and motivation factors for the implementation of food safety management system in the food sector in Harare Province, Zimbabwe".Food Control Journal, 2013;34: 126-131, https://doi.org/10.1016/j.foodcont.2013.04.019

F.I.Dwiantoro,"Pengaruh Gaya KepemimpinanTranformasionaldanTansaksionalTehadapKinerjaOrganisasiMelalui Praktik TQM Pada PT. Pelayaran”. JurnalIlmuManajemen, 2017; 05:1-14,

https://jurnalmahasiswa.unesa.ac.id/index.php/jim/article/download/19175/17509+\&cd=4 $\underline{\& h l=j v \& c t=c \operatorname{lnk} \& g l=i d}$

F.Rahim,V. P.K. Lengkong, L. O.H. Dotulong, "PengaruhKepemimpinanTransformasional Dan KepemimpinanTransaksionalTerhadapKinerjaKaryawanPada PT. PLN Wilayah Sulutenggo". Jurnal EMBA, 2018;4: 3503 -3512, https://ejournal.unsrat.ac.id/index.php/emba/article/viewFile/21623/21326

N.S. Aqmarina, H.N. Utami, A. Prasetya, "PengaruhKepemimpinanTransformasional Dan KepemimpinanTransaksionalTerhadapKepuasanKerja Dan KinerjaKaryawan (StudiKasusPadaKaryawan Hotel Gajah Mada Malang)". JurnalAdministrasi Bisnis,2016;35:164-173, http://administrasibisnis.studentjournal.ub.ac.id/index.php/jab/article/view/1382

R. Wahyuniardi, H.R. Nababan, "PengaruhKepemimpinanTransformasional Dan BudayaOrganisasiTerhadapKepuasanKerja DampaknyaPadaKinerjaKaryawan”,JurnalTeknikIndustri, $\quad$ 2018;19:118-226, https://doi.org/10.22219/JTIUMM.Vol19.No2.118-126

M.Birasnav,"Knowledge management and organizational performance in the service industry: The role of transformational leadership beyond the effects of transactional leadership", Journal of Business Research, 2014;67:1622-1629, https://doi.org/10.1016/j.jbusres.2013.09.006

Williams, Gavin, "Structural Equation Modeling Methodes In SrategyResearch : Application and Issue" Research Methodology in Strategy and Management (Research Methodology in Strategy and Management, Vol. 1), Emerald Group Publishing Limited, Bingley,2004 ; pp. 303-346. https://doi.org/10.1016/S1479$\underline{8387(04) 01111-7}$

N. Cavusoglu, "LISREL growth model on direct and indirect effects using cross-country data," Economic Modelling, 2012;29; 2362-2370, https://doi.org/10.1016/j.econmod.2012.05.025 
O. Boe, "Using LISREL V to Perform a Covariance Structure Analysis of a Tripartite Model of Attitude", Procedia - Social and Behavioral Sciences, 2015;182: 360-363, https://doi.org/10.1016/j.sbspro.2015.04.786

P. Ebrahimi, S. M. Moosavi, E. Chirani, "Relationship between Leadership Styles and Organizational Performance by Considering Innovation in Manufacturing Companies of GuilanProvin",Procedia - Social and Behavioral Sciences, 2016;230: 351-358, https://doi.org/10.1016/j.sbspro.2016.09.044

Qijun, P. J.Batt, "Barriers and benefits to the adoption of a third party certified food safety management system in the food processing sector in Shanghai, China", Food Control,2016;62: 89-96, https://doi.org/10.1016/j.foodcont.2015.10.020

Santoso, P, Purwanto, A., \&Asbari, M.(2019). Influence of Implementation Chain of Custody Forest Management System FSC-STD-40-004 V3-0 to Business Performance of Paper Industriesia in Banten Indonesia, International Journal of Management and Humanities (IJMH), 4(4), 32-36. DOI: https://doi.org/10.35940/ijmh.C0442D0482.124419

Firdaus, R.A.,Purnamasari, D., Akuba, S.F.(2019) The influence of motivation, leadership and perceived workload as intervening on teacher commitment. Journal of Education and Science Technology, 5(3) .DOI :https://doi.org/10.26858/est.v5i3.10847

Purwanto, A., Asbari, M., \&Santoso, P.(2019). Does Culture, Motivation, Competence, Leadership,Commitment Influence Quality Performance? JurnalInovasiBisnis, 6(2), 201-205. DOI: https://doi.org/10.35314/inovbiz.v7i2.1210

Purwanto, A., Asbari, M., \&Santoso, P.(2019).Influence of Transformational and Transactional Leadership Style toward Food Safety Management System FSSC 22000:2018 Performance of Food Industry in Pati Central Java. JurnalInovasiBisnis, 6(2), 180-185. DOI: https://doi.org/10.35314/inovbiz.v7i2.1213

Purwanto, A., Asbari, M., \&Santoso, P.(2019). Can ISO 38200:2018 Wood and Wood Based Product Chain of Custody Increase Businesss Competitiveness of Wood Industries in West Java ?.JurnalHutandanMasyarakat.8 (2).113125.http://dx.doi.org/10.24259/jhm.v11i2.8358

Purwanto, A., Asbari, M., \&Santoso, P. (2020). Effect of Integrated Management System of ISO 9001:2015 and FSSC 22000:2018 Implementation To Packaging Industries Quality Performance at Banten Indonesia. JurnalIlmiah MEA (Manajemen, Ekonomi, \&Akuntansi), 4(1), 17-31. https://doi.org/10.31955/mea.vol4.iss1.pp17$\underline{31}$

Purwanto, A., Asbari, M., \&Santoso, P.(2019).PengaruhKompetensi, Motivasi, Kepemimpinan, KomitmendanBudayaKerjaSistemManajemenIntegrasi ISO 9001, ISO 14000 dan ISO 45001 PadaIndustriOtomotif. JurnalProduktivitasUniversitasMuhammadiyah Pontianak, 6(2),158-166. DOI: http://dx.doi.org/10.29406/jpr.v6i2.1798

Wiguna, R.Ismail, "Validation study of Indonesian mother-infant bonding scale", Asian Journal of Psychiatry, 2019;43: 60-64, https://doi.org/10.1016/j.ajp.2019.05.003 